\title{
Anaerobic Digestion of Lignocellulosic Waste Materials
}

\author{
Vasiliki Kamperidou *(1) and Paschalina Terzopoulou (1) \\ Department of Harvesting and Technology of Forest Products, Faculty of Forestry and Natural Environment, \\ Aristotle University of Thessaloniki, 54124 Thessaloniki, Greece; terzopouz@for.auth.gr \\ * Correspondence: vkamperi@for.auth.gr; Tel.: +30-231-099-8895; Fax: +30-231-099-8947
}

check for

updates

Citation: Kamperidou, V.; Terzopoulou, P. Anaerobic Digestion of Lignocellulosic Waste Materials. Sustainability 2021, 13, 12810. https:/ / doi.org/10.3390/su132212810

Academic Editor: Chunjiang An

Received: 8 November 2021

Accepted: 17 November 2021

Published: 19 November 2021

Publisher's Note: MDPI stays neutral with regard to jurisdictional claims in published maps and institutional affiliations.

Copyright: (c) 2021 by the authors. Licensee MDPI, Basel, Switzerland. This article is an open access article distributed under the terms and conditions of the Creative Commons Attribution (CC BY) license (https:// creativecommons.org/licenses/by/ $4.0 /)$.

\begin{abstract}
Nowadays, the climate mitigation policies of EU promote the energy production based on renewable resources. Anaerobic digestion (AD) constitutes a biochemical process that can convert lignocellulosic materials into biogas, used for chemical products isolation or energy production, in the form of electricity, heat or fuels. Such practices are accompanied by several economic, environmental and climatic benefits. The method of AD is an effective method of utilization of several different low-value and negative-cost highly available materials of residual character, such as the lignocellulosic wastes coming from forest, agricultural or marine biomass utilization processes, in order to convert them into directly usable energy. Lignin depolymerization remains a great challenge for the establishment of a full scale process for AD of lignin waste. This review analyzes the method of anaerobic digestion (biomethanation), summarizes the technology and standards involved, the progress achieved so far on the depolymerization/pre-treatment methods of lignocellulosic biowastes and the respective residual byproducts coming from industrial processes, aiming to their conversion into energy and the current attempts concerning the utilization of the produced biogas. Substrates' mechanical, physical, thermal, chemical, and biological pretreatments or a combination of those before biogas production enhance the hydrolysis stage efficiency and, therefore, biogas generation. AD systems are immensely expanding globally, especially in Europe, meeting the high demands of humans for clean energy.
\end{abstract}

Keywords: anaerodic digestion; bacteria; bioenergy; biogas; biomethanation; digester; lignin; lignocellulosic; methane; waste

\section{Introduction}

In recent years, there have been two major energy crises because of the increase of global energy consumption based on fossil fuels, which corresponds to $80 \%$ of the total required energy [1]. These crises reflect and are strongly associated to the immensely increasing environmental pollution and the growing depletion of fossil fuels. The search for alternative solutions that will constitute clean and renewable energy sources (RES) is at the top of the world agenda and interest [2]. In 2014, the European Council adopted the EU's 2030 Energy and Climate framework that foresees a RES use target of $27 \%$ at EU level until 2030, though no longer connecting RES goals at the national level.

In Europe, a great part of the renewable energy is based on agricultural and forest products. Biomass, because of its high availability, is the most significant and extended renewable resource and, therefore, it could totally or partly substitute the use of fossil fuels $[3,4]$. One of the most substantial benefits from the energy production based on biomass is the low demand for capital investment compared to several other renewable energy sources (wind, solar, etc.) [1]. In this direction, biogas production from organic wastes is characterized by several merits compared to other alternative options, like combustion, bio-liquids and other bio-products generation, such as bioethanol, biobutanol, biohydrogen and biodiesel [1,5]. Among these benefits, the high energy efficiency and the low environmental impact stand out $[1,6]$. Furthermore, the conversion of waste materials into 
value-added products, such as the biofuels (bio-gas) and the resultant bioenergy, complies totally with the principles of sustainability and environmental protection $[7,8]$.

Lignocellulosic biomass could contribute to the production of fuels and chemicals through different biological (anaerobic digestion, etc.), thermochemical (pyrolysis, etc.) and catalytic (transesterification) conversion processes [9]. Anaerobic digestion (AD) constitutes an attractive and effective method of waste treatment and conversion into biogas, in which both pollution mitigation and energy recovery can be achieved. In the future, at least $25 \%$ of bioenergy could be provided by biogas [10]. Biogas, produced by AD, has a number of possible uses in internal combustion engines, in systems with gas turbines and generators, in the production of heat for commercial and residential use, and with proper treatment and upgrading, can be used as transport fuel at a very competitive price.

First of all, it is one of the oldest processes that was used to stabilize solids and biosolids. Specifically, AD involves the degradation and stabilization of organic matter under anaerobic conditions (absence of oxygen) by microbial organisms, whose actions result in the generation of biogas $\left(\mathrm{CO}_{2}\right.$ and $\mathrm{CH}_{4}$ mixture), a renewable energy source [10]. This biochemical process can take place in almost any biological material, though it is favored by hot, humid and airless conditions. It also occurs naturally in the decomposition of vegetation at the bottom of lakes, creating swamp gas that bubbles to the surface and can catch fire. Therefore, many forest, agricultural and industrial wastes are ideal candidates to be used as substrate raw materials for the implementation of $\mathrm{AD}$ (Table 1), since they are highly available and biodegradable. Nowadays, the principal feedstock of biogas generation is crop residues (wheat straw, rice straw, corn straw, and maize, among others) and livestock wastes, contributing to effective waste management [11,12]. The biogas yields for each individual substrate can vary significantly depending on the harvest season and storage atmosphere, which also causes difficulties in yield determination $[13,14]$.

Table 1. Mean values of biogas yield of several lignocellulosic biomass materials.

\begin{tabular}{|c|c|c|c|}
\hline $\begin{array}{l}\text { Lignocellulosic } \\
\text { Biomass }\end{array}$ & AD Conditions & Biogas Yield & References \\
\hline $\begin{array}{c}\text { Switsgrass } \\
\text { (summer harvested) }\end{array}$ & $\begin{array}{l}\text { Co-pretreatment } \\
\text { (Chopped-mulched, } \\
\text { mulched-alkalized), } \\
35^{\circ} \mathrm{C}, \text { AD of } 36 \text { days }\end{array}$ & $\begin{array}{c}\text { Chopped:94.7 } \pm 4 \\
\text { Mulched: } 152.3 \pm 1 \\
\text { Mulched-alkalized: } \\
256.6 \pm 8 \\
\mathrm{CH}_{4} \text { /g.VS }\end{array}$ & {$[15]$} \\
\hline Rice straw & $\begin{array}{c}\text { Fungi pre-treatment } \\
\text { and } S S-A D, 37{ }^{\circ} \mathrm{C}, \\
45 \text { days }\end{array}$ & 152-263 $\mathrm{mL} \mathrm{CH}_{4} / \mathrm{g} . \mathrm{VS}$ & {$[16]$} \\
\hline Sunflower & $\begin{array}{c}35^{\circ} \mathrm{C}, \mathrm{pH} 8.1 \pm 0.3 \\
30 \text { days }\end{array}$ & $\begin{array}{c}210-286.1 \mathrm{~mL} \\
\mathrm{CH}_{4} / \text { g.organic } \\
\text { dry matter }\end{array}$ & {$[17]$} \\
\hline $\begin{array}{c}\text { Birch wood chips hydrolysis } \\
\text { lignin ( } 80 \% \text { lignin) }\end{array}$ & $\begin{array}{l}37^{\circ} \mathrm{C}, 90 \mathrm{rpm}, \\
39 \text { days }\end{array}$ & $125 \mathrm{~mL} \mathrm{CH}_{4} / \mathrm{g} . \mathrm{VS}$ & [18] \\
\hline Wheat straw & $\begin{array}{l}\text { Co-treatment with } \\
\text { lacasse, peroxidase, } \\
\text { AD at } 37^{\circ} \mathrm{C}, 30 \text { days }\end{array}$ & $250.5 \mathrm{~mL} \mathrm{CH}_{4} / \mathrm{g} . \mathrm{VS}$ & [19] \\
\hline
\end{tabular}

High holocellulose (cellulose and hemicelluloses) contents and high $\mathrm{C} / \mathrm{N}$ ratio are the three main characteristics of lignocellulosic biomass wastes [20]. Forest and agricultural biomass and, in some cases, the marine biomass consist typically of the same chemical components of cellulose (30 to $60 \mathrm{wt} . \%$ ), hemicelluloses (12-35\% in wood, $20-40 \%$ in agricultural residues), lignin (23-40\% in wood, $10-40 \%$ in agricultural residues), extractives ( 2 to $15 \mathrm{wt} . \%$ ) and inorganic salts at different levels [6-8]. Cellulose is a linear polymer of $\beta-1,4$ glucan of glucose, while hemicelluloses are formed by a variety of five- and six-carbon monomers [21]. Cellulose presents the tendency to form strong intra- and inter-molecular 
hydrogen bonds, which make cellulose highly insoluble to common solvents and resistant to enzymatic hydrolysis (Galbe and Zacchi 2012). Hemicelluloses present a quite lower degree of polymerization (Saha et al., 2019), are highly hydrophilic and more amenable to hydrolysis [20]. Both can be fermented into sugars necessary in biogas production. Lignin constitutes a phenolic aromatic polymer of high molecular weight, connected to carbohydrates in a tight and complicated way. It plays the role of a resin binder through the cross-linking between cellulose and hemicelluloses to form the amorphous, complex network of the woody tissue cell walls [21]. Lignin is regarded as the most recalcitrant component of wood cell walls. Generally, conifer species have a higher content of lignin compared to broadleaf species. Therefore, cellulose crystallinity, the strong bonds between cellulose and hemicelluloses, the polymerization and nonbonding interactions (steric hindrance) of lignin, all increase the difficulty of enzymatic hydrolysis of cellulose [20,22]. Lignin and hemicelluloses produce a protective sheath around the cellulose, inhibiting the depolymerization of hemicelluloses and cellulose to plain mono-sugars, necessary for productive conversion of biomass into biogas. Therefore, it is essential to pretreat the lignocellulosic raw materials [23].

Pretreatment techniques should be simple, eco-friendly, feasible, and economical. The principal aim of pretreatments is to ease the accessibility of the enzymes to the chemical components (lignin, cellulose, and hemicelluloses), which results in depolymerization of the substrate. Additionally, the use of pretreatment for catalysis of lignocellulosic materials degradation is advantageous for an economical and environmentally friendly production method [23]. Moreover, pretreatment methods should not generate inhibitory substances or cause compounds losses. The production of inhibitory and toxic substances in the material during the pre-treatment process usually adversely affects both the biogas generating bacterial and biodigesters. This constitutes a challenge that raises serious concerns, since most of the benefits coming from pretreatment process could vanish during $\mathrm{AD}$, attributed to the adverse nature of these materials to methane generating bacteria [23].

The single cost of pretreatments is usually similarly high to other production processes $[20,24]$. Unfortunately, no pretreatment technique has been found that is suitable for all types of lignocellulosic materials [23]. Typically, a combination of two or multiple pretreatment methods is more effective and economic, and thus a preferable solution compared to single treatments $[20,23]$.

Although in the last decades, the interest in green and clean energy, new applications and specifically, in the field of waste materials utilization keep rising, the absence of a collective, precise and comprehensive summary of the state-of-the-art and progress achieved so far concerning the method of anaerobic digestion (biomethanation) of lignocellulosic biomass materials has been detected. This review attempts to summarize the progress and emphasize to the research findings of the so far reported studies in literature dealing with the method of anaerobic digestion, the technology involved, different depolymerization/pretreatment methods of lignocellulosic biomass feedstocks towards the improvement of hydrolysis and their characteristics, the upgrading and purification technologies, and the current attempts concerning the utilization of the produced biogas. The current status concerning the establishment of anaerobic digestion units, in Greece, Europe and globally, is being described in an attempt to estimate the perspectives of this conversion method in the coming years.

\section{AD Dynamics and Perspectives}

The share of renewables in global electricity generation jumped to nearly $28 \%$ in 2020 from $26 \%$ in 2019 . Additionally, the use of renewable energy sources increased significantly in the European Union from 8.5\% in 2005 to almost $17 \%$ in 2015 in gross final energy consumption [25]. In June 2018, the EU institutions agreed on a new Renewable Energy Directive for the next decade, including a legally binding EU renewable energy goal by 2030. The biogas sector will undoubtedly contribute to this target. With a total of 17,783 biogas plants and 65,179 GWh of electricity in 2017, the European biogas market is being 
established and mature. On the other hand, the number of biomethane units continues to grow rapidly, from 187 units in 2011 to a total of 540 units in 2017 [25].

Nowadays, the number of AD biowaste plants in operation is 302 in Europe, 92 in Germany, 13 in North America and 6 in Canada. The AD biowaste facilities under development in North America number 20, with 4 others in Canada. There are 2429 agricultural digesters in operation in Europe, 1900 in Germany, 201 in the USA and 100 in Canada [26]. In the United States, most of the produced biogas comes from landfill gas, while in Europe, agricultural wastes are mainly used for this purpose. Colombia, Costa Rica, China, and India have focused on the establishment of a natural gas infrastructure where biogas could be embodied. In parallel, biogas is also used for industrial and urban applications to produce in combination heat and power [13]. AD is a mature technology, which has high potential to offer new strength to the agricultural economy by generating employment opportunities for the rural population and income from waste management and valorization [9].

The expected tendency for the biogas and biomethane sectors in the coming years is integrated into the EU's bio-economy rules. The final solid product of AD can be upgraded and applied as an organic fertilizer, thus replacing the energy-intensive production of conventional fertilizers. Biogas and biomethane can be stocked and eliminate periodical fluctuations in energy request and in the near future, the integration of biogas and biomethane into their regional environment will continue to grow [27]. Another already established trend concerns the use of both heat and power (CHP) and biogas upgrades to a unit to fulfil regional heat demands. The heat can be retrieved for industrial or other activities required close to the infrastructures of biogas units. The remaining biogas is optimized and incorporated into the gas network [25]. In developing countries, biogas is mainly generated in small-scale domestic digesters to offer fuel for cooking and lighting, compared to the developed countries, in which the biogas production focuses on large-scale biogas plants. Many Asian countries (China, Thailand, India, Nepal, Vietnam, Bangladesh, Sri Lanka and Pakistan) perform already extended biogas projects [26].

Both the existing and new AD units turn from the production of electricity from biogas towards the upgrading of biogas to biomethane, since it can be used for the same final applications, such as those of natural gas. In 2018, Belgium, Estonia and Ireland connected the first biomethane plant to their national gas network, representing the total number of European biomethane producing countries by 2018 [27]. According to European Statistics, the highest amount of biogas produced through AD comes from Germany, Italy, Czech Republic and France, followed by biogas from gas recovery in the United Kingdom, Italy, France and Spain. Biogas produced in anaerobic digesters is predominant bio-fuel used in Germany, Italy, Denmark, the Czech Republic and Austria (Table 2). Landfill biogas is prevalent in the markets of Portugal, Estonia, Ireland or Greece and the United Kingdom, while in a few countries, such as Sweden, Poland and Lithuania, biogas from wastewater treatment is prevalent. Most of the biomethane plants are located in Germany (185 plants), the United Kingdom (80 plants) and Sweden (61 plants) [26,28]. In 2015, there were more than 17,400 biogas plants in Europe of various types and sizes, ranging from small anaerobic digesters on farms to large fusion units, with a total installed capacity of more than 10,100 MW [26]. Most biogas plants range from 100 to $500 \mathrm{~kW}$ (electric power). Therefore, Europe is the world's largest producer of biomethane [25,27-30].

The technical potential of biogas in EU according to estimations of the German Biomass Research Center is between 151-246 billion $\mathrm{Nm}^{3}$ biomethane from $\mathrm{AD}$ and synthetic gas produced through gasification, including 66 billion of wood biomass, 11 billion $\mathrm{Nm}^{3}$ of grassy biomass, $48-143$ billion $\mathrm{Nm}^{3}$ of energy crops and 26 billion $\mathrm{Nm}^{3}$ of liquid biomass. According to estimations obtained through the Green Gas Networks project, by 2030, a production of 20 to 30 million $\mathrm{Nm}^{3}$ /year of biomethane (counting crude biogas, upgraded biogas and related) could be accomplished from the technical capacity of 151 billion and 3 billion could reach $18-20$ billion $\mathrm{Nm}^{3}$ in 2030 [31]. The AD process, as well as the production and utilization of biogas, should comply with the international or European relevant 
standards, concerning the AD and biogas production processes (e.g., ISO 13975: 2019, ISO 13641-1: 2003, ISO 15985:2014, EN 16723-1: 2016, EN 16723-2: 2017, ISO 20675: 2018).

Table 2. The installed capacity of renewable energy sources and the production of electricity from biomass in different countries $[27,28]$.

\begin{tabular}{ccc}
\hline Countries & Installed Power 2015 (GW) & Production of Electricity from Biomass (TWh) \\
\hline EU & 30 & 178 \\
\hline UK & 16.7 & 69.1 \\
\hline China & 10.3 & 41.6 \\
\hline Brazil & 9.7 & 32.9 \\
\hline India & 4.7 & - \\
\hline Japan & 4.7 & 30.2 \\
\hline
\end{tabular}

In Greece in 2015, there were 22 biogas units operating, while the installed capacity exceeded 45 MW. The most important units in Greece are in the landfill of "Ano Liossia", where a significant investment has been made in electricity production by utilizing the produced biogas in Internal Combustion Engines, with an installed capacity of $23.5 \mathrm{MWe}$. In "Psyttalia", there is another unit for the energy utilization of the sludge produced by the wastewater treatment plant, with cogeneration, with installed capacity of $11.4 \mathrm{MWe}$, but also the one in "Tagarades" of smaller capacity (5 MWe) [32]. The management and energy of organic waste is a serious problem in Greece, since annually, about 18 million tons of unused organic waste is generated (excluding organic municipal and biological wastewater), creating significant environmental problems. By utilizing the energy of this waste, through the process of anaerobic digestion, biogas can be produced, supplying power plants with a total installed capacity of approximately $350 \mathrm{MW}$ [33].

\section{AD Process/Technology}

AD process, named also as biomethanation, is the bacterial depolymerization of organic matter in the absence of oxygen. This biological process produces the biogas, consists mainly of methane and carbon dioxide. Biogas production process demonstrates benefits such as organic waste control, limiting toxic gases emissions, and production of superior and economical fertilizer [23]. The investment cost to convert lignocellulosic materials into heat and power, using the $\mathrm{AD}$ technology is higher compared to the respective cost of gasification technology. Nevertheless, especially the upgraded biogas demonstrates higher dynamics of heat and power production compared to synthetic gas [13]. Additionally, the faster renewable biogas could provide important environmental benefits compared to natural gas. Koornneef et al. [13] state that biogas use could contribute to the avoidance of around $8 \mathrm{Gt} \mathrm{CO}_{2}$-eq of $\mathrm{GHG}$ emissions in 2050.

The AD technologies that operate worldwide are the Liquid AD, High Solid AD, AD flow connection, High rate AD and the micro AD Flexibuster, which is a self-contained anaerobic digester designed to treat food and biological organic waste. It is suitable for food producers, retail chains and hosting facilities. Moreover, it converts bio-waste into electricity, heat and organic fertilizer. It presents significant benefits such as revenue from electricity and heat, and reduction of waste disposal costs. Another AD technology is Coexpansion [34]. In Canada, the most utilized/performed AD technologies are the Liquid AD and the High solid AD [34].

Biogas is a result of a complex depolymerization process composed of four interdependent, sequential, parallel stages; those of hydrolysis, acidogenesis, acetogenesis, and methanogenesis (Figure 1). The organic matter, which consists of carbohydrates, lipids, proteins, and fats, is first decomposed into its building blocks like simple sugars, amino acids, and fatty acids, through the hydrolysis stage. These are converted to carboxylates via acidogenesis or to acetate and hydrogen and carbon dioxide via acetogenesis, where 
such conversion is also carried out by the generated carboxylates. More specifically, during acidogenesis, these fermentative microorganisms create the acidic environment in the reactor and produce $\mathrm{NH}_{3}, \mathrm{CO}_{2}, \mathrm{H}_{2}, \mathrm{H}_{2} \mathrm{~S}$, organic acids, and shorter volatile acids with traces of other by-products. Butyric acid, acetic acid, propionic acid, etc., are being released in this stage. In acetogenesis, a derivative of acetic acid (acetate) is generated from carbon and energy sources by bacteria called acetogens. Acetogens catabolize some of the products of acidogenesis step into acetic acid, $\mathrm{CO}_{2}$, and $\mathrm{H}_{2}$ and also degrade the biomass to an appropriate level that would be helpful to methanogens during bio-methanation [23]. Lastly, the products of acetogenesis (hydrogen, $\mathrm{CO}_{2}$, etc.) are converted to methane and $\mathrm{CO}_{2}$ through methanogenesis [35]. Methanogenesis has two general pathways that concern the exploitation of $\mathrm{CH}_{3} \mathrm{COOH}$ and $\mathrm{CO}_{2}$ obtained from the first three $\mathrm{AD}$ stages to release $\mathrm{CH}_{4} \cdot \mathrm{CO}_{2}$ can be transformed into $\mathrm{CH}_{4}$ and water through the process, while the major mechanism to liberate $\mathrm{CH}_{4}$ during methanogenesis is the path concerning $\mathrm{CH}_{3} \mathrm{COOH}$, and this results in the release of $\mathrm{CH}_{4}$ and $\mathrm{CO}_{2}$, the two basic products of AD process [23].

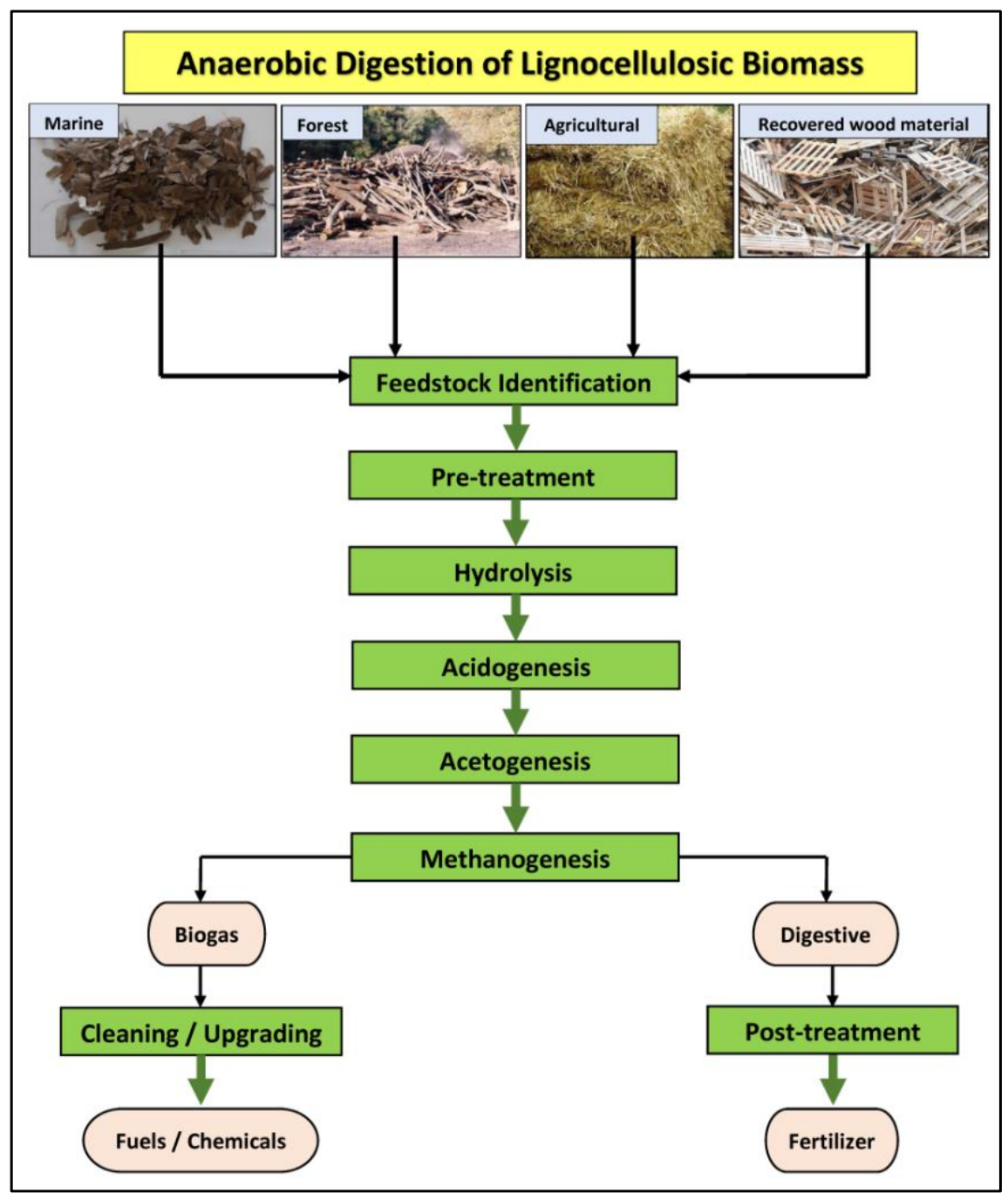

Figure 1. Main stages of anaerobic digestion of lignocellulosic biomass (in green) and main resultant products (in beige).

Each step involves the participation of different microorganisms that act synergistically to convert molecules from one form to another, plainer one, through biochemical reactions [20,36]. The abovementioned stages are related to one another, and any of these stages can be considered as the restraining step in AD process [13]. Usually, the stage of methanogenesis is the one that determines the speed of the whole process, because 
of the small specific growth rate of methanogenic bacteria, compared to microorganisms involved in AD process. However, when the substrate intended to be treated presents a high content of organic solids, the hydrolysis phase is usually the defining stage of the whole process [37].

The respective industrial process is implemented using one-step or two-step reactors in singe-phase or double-phase as a specific batch or applying continuous operation, with or without liquid phase recirculation [13]. Depending on the feedstock and system design, biogas typically consists of $55-70 \% \mathrm{CH}_{4}, 25-40 \% \mathrm{CO}_{2},<2 \% \mathrm{~N}_{2},<0.5 \mathrm{O}_{2},<0.5 \% \mathrm{H}_{2} \mathrm{~S}$, $1-5 \% \mathrm{H}_{2} \mathrm{O},<0.5 \% \mathrm{NH}_{3}, 0-50 \mathrm{mg} / \mathrm{m}^{3} \mathrm{SiO}, 6-7.5 \mathrm{kWh} / \mathrm{m}^{3} \mathrm{Hs}$ [38,39]. Generally, raw biogas provides a methane concentration of $50-70 \%$ and its $\mathrm{HHV}$ is approximately $37.78 \mathrm{MJ} / \mathrm{mn}^{3}$. Raw biogas energy content could replace $0.65 \mathrm{~L}$ of crude oil [13].

The AD process should fulfill several crucial requirements to achieve an effective substrate degradation, associated to the standard operation characteristics like temperature, $\mathrm{pH}$, nutrient (C-N-P) supply, and redox dynamics [13]. The optimal $\mathrm{pH}$ for methanogenesis lies from 6.6 to 7.5, whereas acidogens are more adaptable to a $\mathrm{pH}$ between 3 and 12 [40]. $\mathrm{pH}$ shift from neutral to lower than 6.5 is a common practice to avoid $\mathrm{CH}_{4}$ formation and lead to higher volatile fatty acids yields because of their accumulation during digestion that would directly decrease $\mathrm{pH}$ and inhibit methane formation without peripheral completion of methanogenesis inhibitors. Additionally, overload acids accumulation can lead to self-inhibition [20].

The efficiency of the anaerobic digestion process is dependent also on temperature, hydraulic retention time, blending, $\mathrm{C} / \mathrm{N}$ ratio, surface area, feedstock loading rate, the content of total solids and volatile solids, theoretical methane yield, biochemical methane potential, organic loading rate, shear stress and inhibitors $\left(\mathrm{NH}_{3}\right.$, furfural, etc.) $[9,13]$. Some of these parameters could be adjusted during the biomethanation to ensure a beneficial AD process and biogas yield [23].

Lignocellulosic residual biomass is usually characterized by a C/N ratio over 40 [20]. The concentration of $\mathrm{C}$ and $\mathrm{N}$ provides an image of the nutrients level of the AD substrate. More specifically, very high or low $\mathrm{C} / \mathrm{N}$ ratio could affect the total ammoniacal nitrogen $\left(\mathrm{NH}_{3}-\mathrm{N}\right)$ and fatty acid production that may also affect the biogas production yield and rate [9]. In general terms, a $\mathrm{C} / \mathrm{N}$ ratio of 20-30 is considered as a friendly environmentally that could balance $\mathrm{C}$ and $\mathrm{N}$ nutrients necessary for microbial growth. A low $\mathrm{C} / \mathrm{N}$ ratio could release excessive ammonia, leading to a $\mathrm{pH}$ increase and an unbalance nutrient composition, which are regarded to inhibit methanogenesis [20]. Redox potential should be between $+400 \mathrm{mV}$ and $-300 \mathrm{mV}$ [13].

The biogas is produced in separate anaerobic waste digesters and is the result of anaerobic waste digestion that takes place over a period of days or weeks [23]. Minimum 3 weeks are required for the AD microorganisms to be familiar with the new feedstock/substrate and conditions (temperature, $\mathrm{pH}$, etc.). As evidenced, the retention time should be between 10 and 15 days [9]. The operating temperature in the digester constitutes a crucial factor for the effectiveness of AD process and a tool for control of the whole process $[13,23]$. The microorganism species determines the temperature range that should be established and could vary among psychrophilic (i.e., $15-25^{\circ} \mathrm{C}$ ), mesophilic (i.e., $35-40^{\circ} \mathrm{C}$ ) and thermophilic (i.e., 55-60 ${ }^{\circ} \mathrm{C}$ ) [9]. Mesophilic and thermophilic are the two optimal ranges of temperature for the AD process. Most of the AD plants around the world choose the mesophilic range, since the heat required for stabilizing the final temperature is low and a thermal stability is easier to be achieved at such temperatures. Nonetheless, thermophilic plants require more energy and accuracy to operate, but thermophilic range is needed when AD should be rushed, leading to increased biogas production and lower number of pathogens in effluent slurry [23].

There are variant ways to enhance biogas production, as reported in the literature, such as pretreatments, co-digestion, bioaugmentation, biohythane, temperature, organic loading rate, and reactor design [23]. 


\section{Progress on AD Process Improvement}

In general, significant research attempts have been implemented so far, to be familiar with the mechanism and control of AD deterrence agents, and some of the most significant are summarized hereupon. Ye Chen et al. [41] provided a study on the deterrence of the biomethanation process. Inhibiting substances commonly found in anaerobic digesters include ammonia, sulfide, light metal ions, heavy metals and other organic substances. Due to the variance in AD inocula used, the feedstock chemical compounds, and the experimental methods applied, inhibition is caused by toxic substances that greatly vary. In combination with other wastes, adapting microorganisms to inhibitors, and incorporating methods to remove or neutralize toxic substances prior to AD can significantly improve the efficiency of waste treatment. Aziz et al. [42] identified the fact that the use of industrial inoculation as a catalyst, in several substrates (rice waste, etc.), could produce satisfying yields of energy. On that account, techniques that increase the lignocellulosic biomass accessibility towards the achievement of anaerobic microbial decomposition are highly demanded [38].

\subsection{Pre-Treatment of Biomass Materials}

Using some pretreatment methods, yield of fermentable sugars can reach to $90 \%$, which is less than $20 \%$ without any pretreatment [21]. Therefore, main aims of the pretreatments are to facilitate the availability of the cellulose and hemicelluloses to enzymes and lead to depolymerization of the biomass material, avoid severe destruction and loss of holocellulose material, ensure that inhibitors will not be released during treatment, let the product be of low cost and footprint [23]. Pretreatment methods are usually separated into four categories, including physical, chemical, biological, and combination of pretreatments [20]. The most commonly performed pretreatment practices to improve the degradation and digestion of lignocellulosic feedstocks nowadays are dilute acid hydrolysis, steam explosion, alkaline activation, dimensions decrease, and hot water treatment, because of their high perspective for easy industrial scale-up [13].

Physical/mechanical pretreatment of woody biomass constitutes a crucial step in improving the ease of access of enzymes, particle compression and structure and total conversion of this substrate into biogas without the parallel production of dangerous substances. Such a method generates new surface area, improves rheological properties, and improves the density (basic or bulk) of the feedstocks [23]. Dimensions reduction is usually necessary before several chemical or biological pretreatments. In previous studies, researchers were usually grinding the substrate material into dimensions $<2 \mathrm{~mm}$, which may not be cost-effective and optimal for large scale feedstock [20]. Nevertheless, particle size reduction methods (milling, grinding or chipping methods) increase the surface area of substrate and reduce the polymerization level and cellulose crystallinity. Particles of $10-30 \mathrm{~mm}$ could be shaped through chipping, while smaller particles (till $0.2 \mathrm{~mm}$ ) can be achieved through grinding or milling techniques (hammer, vibratory, colloid, and two-roll milling). Wet disk milling and ball vibratory techniques have been proven to be more efficient and less energy consuming [23]. Size reduction less than $0.4 \mathrm{~mm}$ does not significantly affect the hydrolysis rate or biogas production [23].

Unfortunately, particle dimensions decrease is an expensive practice which corresponds almost to $33 \%$ of the total energy required for the whole procedure. Bearing in mind the extremely high energy requirements for dimensions reduction and enormous cost of energy, the method itself is not considered cost-effective. As a result, decreasing the energy required and improving the efficacy of milling/grinding of biomass is of great importance to improve the finance and perspectives of the whole procedure. Combination of pretreatments could be applied to abstain the cost of such an intensive particle size reduction process, such as a combination with chemical pretreatment (alkaline, $\mathrm{H}_{2} \mathrm{O}_{2}$ ) that could be beneficial for lignocellulosic biomass hydrolysis [23].

High pressure homogenizing is a much attractive mechanical pretreatment technique used for cell walls breakage, used to rearrange the complex network of lignocellulosic 
materials and upgrade the attack of enzymes without causing hemicelluloses losses [43]. The homogenizer is appropriately equipped to operate towards the generation of uniform shape of particles delayed in the liquid, by utilizing a pressure pump to drive the liquid through a particular valve to achieve and complete homogenization. During operation, high-pressure homogenization can be accomplished when the pressure is about 150-200 MPa, or ultra-high-pressure uniformity at a pressure of up to 350-400 $\mathrm{MPa}[23,44]$.

In extrusion pretreatment, an extruder of single or twin screw is employed, and biomass is exposed to heat, compression, friction and shearing forces, in order for the substrate material to be physically destroyed and chemically modified. The pressure release taking place at the exit of the barrel of extruder causes a structural alteration of the biomass material, which promotes its subsequent biodigestion [45].

Ultrasonic treatment is a method that destructs, through the ultrasound waves, the woody biomass structure and alters its chemical composition [23]. This pretreatment produces small cavitation bubbles $\left(\right.$ at $50^{\circ} \mathrm{C}$ ) that depolymerize the cellulose and hemicelluloses network. As a result, this process improves the accessibility of downgrading enzymes to the cellulose for effective depolymerization into plain and uniform glucose molecules. Ultrasonic frequency and reaction time and sonication power level and time highly influence the ultrasonic field and, therefore, feedstock pretreatment. Factors such as the digester size, type, and solvent used also have significant impacts on the biomethanation process $[23,46]$.

Pretreatment of high hydrostatic pressure is a promising method for the processing of lignocellulosic materials to ensure high biogas production, since treatment duration and pressure level can be altered to adjust the enzymatic hydrolysis level. This pre-treatment method involves pressure appliance and aims either on sharing the pressure comparatively in all parts of the biomass, independently of the shape and dimensions or benefits the entire subsequent reactions and changes that involve volume decrease. The level of pressure affects only the hydrogen bonds, reducing the treatment duration. The applied pressure modifies the structure of the enzymes and affects their power and way of action, changing the series of reactions that take place and the structural network of biomass [47].

Gamma ray irradiation effectively improves the enzymatic hydrolysis of lignocellulosic materials. This irradiation is obtained from radioisotopes such as Cesium-137 and Cobalt-60. Ionizing radiation could interfere freely in the woody materials and modify the lignin network and cellulose areas of high crystallinity. The subsequent impact is promoted by the liberation of free radicals, which degrade after radiation performance faster than the amorphous areas, whereas degradation at a specific time from the areas of high crystallinity as well results in further depolymerization of the substrate. This concerns the alterations of the connection among the holocellulose (cellulose and hemicelluloses) and bonds within the substrate, surface area raise, decrease in the range of dispersion, reduction of particle dimensions, and increase in thermo-degradation process of the substrate material studied. This technique is, in general, effective on depolymerizing of cellulose, and this obliged its application combined with several different practices, such as alkaline or hydrothermal or steam-explosion towards hemicelluloses and lignin depolymerization [23].

Pretreatment method that involves pulse electric field focuses on the subjection of the cellulose of lignocellulosic biomass through opening the cavities within the pit membranes of cells and improving the potential of the agents to convert the cellulose into plain glucose molecules. Throughout the pretreatment, biomass materials are subjected to a brief (nanoseconds-milliseconds) and sudden burst of high voltage of $5.0-20.0 \mathrm{kV} / \mathrm{cm}$. The advantage of this treatment is mainly the low power consumed, attributed to the short time $(100 \mu \mathrm{s})$ of the pulse duration, usually performed at ambient conditions (temperature, pressure, etc.). The necessary equipment is quite plain. Further research is necessary to assess the effectiveness of this method concerning the structure of lignocellulosic substrates [48].

Thermal treatment is a technique in which the biomass materials are being exposed to heat at elevated temperatures [49]. Temperatures above $100{ }^{\circ} \mathrm{C}\left(150-200{ }^{\circ} \mathrm{C}\right)$ make lignin to be plasticized and hemicelluloses to be dissolved, while the groups of hemicelluloses responsible for branching usually affect their composition and structure. There 
have been several different ways by which the thermal treatment technique can be performed to different substrates [49]. The release of dangerous compounds like furfural, hydroxymethylfurfural, and phenolic acids because of the high temperatures applied could inhibit the process. Thermal treatment could be preferable in regions where the surplus heat coming from a neighboring industry is available to be utilized, in order to decrease the cost of energy consumed during temperature raise.

Liquid hot water treatment is a method that involves hot water $\left(170-230^{\circ} \mathrm{C}\right)$ and pressure (till $5 \mathrm{MPa}$ ). It tends to depolymerize hemicelluloses and remove lignin, which make cellulose highly accessible, whereas the generation of inhibitory substances at high temperatures is obviated. Typically, the pulp and paper industries have been applying this method as pre-treatment of wood and other lignocellulosic substrate materials. This technique is performed following three different approaches: counter current, co-current, and flow-through pre-treatment. As evidenced, at temperature ranges of 200 to $210{ }^{\circ} \mathrm{C}$, biogas production declines, which could be associated with the potential production of refractory materials [23].

The steam explosion method requires low energy, limited chemicals, no cost of recycling, and is environmentally friendly. The biomass is subjected to steam for $30 \mathrm{~s}$ to $30 \mathrm{~min}$ at a specific temperature $\left(120-260^{\circ} \mathrm{C}\right)$ and pressure (5-20 bars), and it is considered a cost-effective pretreatment method. However, at times, the xylan portion is partially debased and inhibitors may be produced during the process. The already coarsely chopped biomass raw materials are placed in a pressure vessel with an atmosphere of steam under pressure [23]. After the pretreatment, the substrate will be transferred into a flash tank under atmospheric pressure, which is going to result in direct material de-compression and destruction. Especially materials that are included to those bearing acetyl groups generate organic acids throughout the steam explosion process, which therefore could catalyze the hydrolysis reactions on the substrate. The hemicelluloses and lignin start to degrade or become dissolved because of these acids presence. To promote the steam explosion pretreatment as much as possible, additional acid or alkali could be introduced in this direction on the mixture. The results of this treatment are dependent mainly on factors such as the biomass moisture content, the dimensions of particle, treatment temperature and duration [50].

Hydrothermal treatment of lignocellulosic biomass wastes at $200{ }^{\circ} \mathrm{C}$ and hydrogen catalyst is a low-cost and eco-friendly method of high improvement efficiency, concerning hemicelluloses and lignin partial removal and hydration of cellulose, since it does not require chemicals [51-53]. Hydrothermal treatment generally could remove higher amounts of hemicellulosic polymers and a lower amount of lignin in biomass materials by depolymerizing them into plain parts of oligomers and additionally cut off the initial difficulty and impermeability of the biomass tissue network. The most significant impact among the factors influencing this method is demonstrated by the temperature and at less extent by duration, etc. [52]. The temperature applied usually ranges between 90 and $260^{\circ} \mathrm{C}$. The generation of inhibitory substances such as 5-hydroxymethylfural and furfural that affect the methanogenesis are reported (at $200^{\circ} \mathrm{C}$ ).

Among physical pretreatment technologies, the use of microwave energy is popular [20]. Microwave is basically an electromagnetic radiation that uses wavelengths of $1 \mathrm{~mm}-1 \mathrm{~m}$, recorded in between 300 and $300,000 \mathrm{MHz}$ on the electromagnetic spectrum and they are non-ionizing radiation that conveys energy selectively to depolymerize the different components of biomass. This method is used to break down the tissue cell walls and the cellulose crystals tight network, increasing the surface area and improving in this way the availability of components [54]. The last years microwave heating seems to have contributed to the optimization of processes such as hydrolysis, esterification, oxidation, and alkylation [55]. In order to further improve the effectiveness of the process, mild alkaline reagents can be employed. This method has been gradually scaled-up to pilot scale and seems to be very promising concerning its future development [56]. At present, the biomass pre-treatment method through microwave irradiation can follow the approach of 
"solvolysis" based on microwave, implemented under lower temperatures $\left(<200{ }^{\circ} \mathrm{C}\right)$ and "pyrolysis" based on microwave, in which lignocellulosic materials are exposed at higher temperatures $\left(>400{ }^{\circ} \mathrm{C}\right)$ in the absence of oxygen, in order to convert the substrate into liquid or gaseous bio-products, taking advantage of specific catalysts. Microwave radiation demonstrates merits like direct heat transfer and lower reaction duration, homogenous and specific volumetric heating performance, low level of thermodegradation or production of by-products/intermediate-products, simplicity of operation, and efficacy compared to conventional thermal treatment [57]. The effectiveness of this method is mainly dependent on the dielectric properties of the biomass material that highlight the ability of the materials to stock electromagnetic energy and utilize it as heat. Even though biomass normally absorbs at a low rate by microwave, this could be enhanced using biomass substrates of high moisture and ash contents [58]. As it was evidenced, concerning co-pretreatment of microwave and alkali addition, even though the augmentation with microwave did not exhibit the synergistic action that was foreseen using co-alkaline pretreatment in comparison to the mono-alkaline treatments [20].

Alkali activation $\left(\mathrm{NaOH}, \mathrm{Ca}(\mathrm{OH})_{2}\right)$ is the most effective chemical pretreatment and it has been confirmed in industrial applications, irrespectively of their widely accepted disadvantages of toxicity and pollution [20]. Using alkaline in lignin removal is very effective, and in parallel, cellulose content is kept at high levels. Alkaline treatment of biomass results in fiber swelling, creating a larger surface area and higher accessibility of the components, the polymerization level and crystallinity level are being decreased and in parallel, the bonds of lignin with holocellulose polymers are degraded, also decreasing the recalcitrance of the lignin network [59]. The major disadvantage of this method is that the downstream processing is not economical, since the process requires great water amounts to clear off the salts from the biomass. Alkali activation is efficient in lignin solubility. The alkali residual quantities that remain in the biomass substrate after treatment are limited and contribute to neutralizing the $\mathrm{pH}$ subdue throughout the acidogenesis step of AD. Therefore, alkaline treatment seems to be more appropriate for $\mathrm{AD}$ when it equates to acid pre-treatment [60].

Exposure of biomass to active chemical reagents constitutes the chemical pretreatment method, which is more preferable than other physical or biological techniques, because of its high efficacy, higher biogas yields that base on the improvement of depolymerization of complex biomass substrates and recalcitrant components. Some of the chemical substances, investigated so far, concerning the treatment of biomass materials prior to $\mathrm{AD}$ providing positive results are among others, the hydrochloric acid, potassium hydroxide, sulfuric acid, lime, aqueous ammonia, sodium hydroxide, acetic acid and hydrogen peroxide [23].

Acidic pretreatment is one of the most popular pretreatment techniques for biomass substrates. Pre-treatments using either diluted or pure acid $\left(\mathrm{H}_{2} \mathrm{SO}_{4}, \mathrm{HNO}_{3}, \mathrm{HCL}\right)$ have been performed and evaluated so far, using high temperatures, or combined with other treatments such as steam explosion [61]. The use of an acid of high concentration can make lignin and hemicelluloses of the substrate be dissolved, though it is quite crucial to the acid to be retrieved. Even though lignin is redistributed, it does not get dissolved when an acid of low concentration is being used. In order to ensure the neutral $\mathrm{pH}$, the process of neutralization prior to $\mathrm{AD}$ is necessary. This pretreatment is reported as one of the most frequently applied conventional pretreatment practice of biomass substrate materials. Nevertheless, the generation of inhibitory substances such as phenolics, furfurals and aldehydes makes it not so preferable. Since acids present a strong corrosive and toxic action, the digester could be built in a way that can withstand these characteristics [62].

Another quite efficient chemical treatment is the performance of oxidizing agents such as ozone, $\mathrm{FeCl}_{3}$, hydrogen peroxide, and oxygen/air, in order to degrade the polymers of lignin and hemicelluloses of biomass, as well as to improve cellulose hydrolysis [63]. According to the procedure of this treatment, the abovementioned substances (e.g., hydrogen peroxide or per-acetic acid) is being diluted in water and spouted on the substrate material, 
having the intention to depolymerize lignin, though during this process, a great loss of hemicelluloses is reported. During the method of wet oxidation, $\mathrm{O}_{2}$ is being introduced into treatment digester concerning temperatures till $200{ }^{\circ} \mathrm{C}$ and pressure approximately till 1.5 MPa [64]. As has been reported recently, in substrates of $\mathrm{pH}>10$, hydrogen peroxide introduction is the optimal choice for high efficiency. In cases of substrates with $\mathrm{pH}<10$, lignin was not at all influenced. During the specific procedure, lignin is converted into acids, which catalyze further the lignin degradation. In case that these produced acids act as inhibitors, they should be removed [65].

Ozonolysis, namely the pre-treatment of lignocellulosic materials with ozone is considered effective, but neither a low-cost nor a suitable method for industrial scale applications. Ozone depolymerizes the lignin network, but not the holocellulose. This method can be implemented at lower temperatures and pressures in comparison to other chemical pretreatment methods. Furthermore, this method does not generate toxic or inhibitory substances and, therefore, it is environmentally friendly and does not adversely affect the subsequent processes of hydrolysis [66].

Sulfite pretreatment is a popular, highly effective, easy and innovative pretreatment technique that triumphs over the lignocellulosic materials resistance to depolymerization. The biomass is exposed to magnesium or calcium sulfite to decrease first of all the lignin and hemicelluloses contents, while secondly, the dimensions of the already treated substrate is being intensely shortened with a mechanical disk miller [67]. This technique decreases the time and energy consumption to $1 / 10$ required for the substrate dimensions decrease. The conversion rate of cellulose to sugars is very high, and the degradation rate of lignin as well. This process is suitable for the treatment of different substrates with high potential to scale the whole production process up to industrial level, by converting the existent infrastructures into the respective ones required for the bio-fuels production. However, the high quantities of water used for the cleaning of the particles after pretreatment, glucose degradation and a loss of a part, and high cost of the chemicals retrieval used during pretreatment are included among the main limitations of this technique [68].

Organosolv pretreatment method involves the use of organic solvents such as methanol, ethanol, ethylene glycol and acetone potentially in the presence of salt catalyst to pretreat biomass at high temperatures $\left(\approx 200{ }^{\circ} \mathrm{C}\right)$. Aqueous organic solvents are applied to biomass at a specific temperature and pressure. This treatment aims at the extraction of lignin to be further utilized, while holocellulose is released to be further depolymerized by AD. The bonds within the molecules are being disarranged by the organic solvent, in order to act towards the depolymerization of biomass structure by the enzymes. The solvent retrieval through evaporation and condensation is required to limit the high cost of this technique. The catalyst kind and quantity, the reaction time, solvent concentration and temperature are factors that determine many characteristics such as fiber length, cellulose polymerization level and crystallinity level, etc. of biomass. Inhibiting substances of the components bio-degradation are generated when the process temperature and acid concentration are high in combination with a longer time of reaction [69]. It is of great importance to remove the solvent, because of its toxicity against microorganisms' development, action and biodigestion [70]. Generally, the retrieving of each of the components of woody substrate materials is feasible, and such a biorefinery approach could contribute to the limitation of the whole process cost. Nevertheless, a high quantity of downstream wastes and appropriate equipment required are some of the main drawbacks, while another limitation of this method constitutes the risk raised by the flammability of these solvents.

Carbon dioxide explosion is a biomass pretreatment method implemented under supercritical $\mathrm{CO}_{2}$ with the gas to have the role of hydrolysis agent. This supercritical $\mathrm{CO}_{2}$ is discharged in a chamber at high pressures, in which the biomass has already been introduced [71]. When the final temperature becomes established in the chamber, it remains in this state for some minutes. $\mathrm{CO}_{2}$ is introduced to the raw material at high pressure and releases carbonic acid that hydrolyzes the hemicelluloses. When this under pressure gas is being liberated, it tends to destroy the lignocellulosic arrangement, improving the 
components accessibility. This technique seems to be appropriate for raw materials of high moisture content, since the hydrolytic action is higher in this case [72]. This method is characterized by low cost of $\mathrm{CO}_{2}$, low temperature, absence of toxins, and high solid capacity. However, issues to be addressed are the high cost of reactor, which is required to withstand higher pressure that is associated with the method, limiting its wider commercial use, as well as the high thermal energy required for the disintegration of biomass.

Another cost-effective and highly efficient pre-treatment practice is ammonia fiber explosion, in which ammonia in liquid form is utilized to pre-treat lignocellulosic substrate materials. Aqueous ammonia is being used in a batch reactor at temperature range of 30-60 ${ }^{\circ} \mathrm{C}$ that decreases the liquid performance throughout the procedure [73]. During pretreatment, biomass substrates are exposed to heat using as a means the liquid ammonia (1:1) in an enclosed chamber approximately at $60-90{ }^{\circ} \mathrm{C}$ and $3 \mathrm{MPa}$ pressure for approximately 30-60 $\mathrm{min}$. After $5 \mathrm{~min}$ at this temperature, the chamber's valve is opened and the pressure is released explosively, resulting in the removal of ammonia and the subsequent temperature decrease [74]. This method presents variant similarities to the method of steam explosion that has been previously described, though, ammonia is used instead of steam/water. This process leads to cellulose swelling, cellulose crystallinity decrease and holocellulose accessibility and reactivity increase. In parallel, the lignin network is modified, increasing the permeability and digestibility. Through this method, over $90 \%$ of cellulose and hemicelluloses is possible to be converted into plain sugars [75].

Ionic liquids application to pretreat lignocellulosic materials recently attracts much of the interest. They are green solvents, exclusively composed of ions, characterized by low melting points $\left(<100{ }^{\circ} \mathrm{C}\right)$, heat stability, trivial vapor pressure, and high polarity level. The most frequently used ionic liquids are imidazolium salts. They are suggested to cope with biomass component for hydrogen bonds generation resulting in destructing its network. If suitable anti-solvents could be chosen, up to $80 \%$ of the hemicelluloses depolymerization could be obtained [76]. Furthermore, combining other treatments, such as chemical treatments, to this method is required sometimes to equalize the modified biomass material, and this can increase the production cost [77]. However, ionic liquids do not present necessarily successful results, when combined with other chemical pretreatments. Generally, the high expense for the ions and the necessity to retrieve and recycle the ionic liquids constitute the main drawbacks of this method.

Deep eutectic solvents display many properties related to that of ionic liquids. They are substances which ordinarily consist of low-cost and non-toxic constituents that acquire the ability of self-integration, mostly through $\mathrm{H}_{2}$ bonding. These solvents generate eutectic composition that lower the melting point compared to the one of their independent constituents. Most of these solvents employ $\mathrm{H}_{2}$-bond acceptor, mainly choline chloride. This substance is a low-cost, compostable, and non-toxic ammonium salt, which could be obtained from lignocellulosic substrates and tends to synthesize solvents with H donors, such as carboxylic acids, asurea, and polyols. The referred solvents could be obtained from natural sources and can be recycled efficiently [23].

Concerning chemical pretreatment, the reagents high cost and the necessary addition of more parallel operations, such as neutralization and the necessity for specified digestion vessels demonstrating high strength against the corrosion, are the recorded drawbacks. Furthermore, the production of inhibitors produced during the treatment is a crucial parameter to be faced, since they prevent delay or intensively limit the hydrolytic action and conversion effectiveness of substrate materials into biogas. In general, increasing the efficiency and limiting the generation of inhibitors employing a combination of different chemicals (diluted, not pure), and variant pretreatments could contribute to cost reduction [20,23].

Enzymes immobilization on nanoscale materials is considered a non-typical and novel method to improve the catalytic action of enzyme. The real enzyme immobilization through the use of cross-linking components offers an expansion that reduces stiff barrier between enzyme and the substrate resulting in an improvement of the enzymes versatility. $\mathrm{Ag}, \mathrm{MgO}, \mathrm{Fe}_{2} \mathrm{O}_{3}$, nZVI or other nano-particles, can be absorbed and destroy the membranes 
of the biomass or wood cells. Nanomaterials usually succeed to enhance the efficiency of not mobilized enzymes, since they offer increased surface area for the enzyme attachment, improving the enzyme load that corresponds to a substrate mass unit. The incorporation of nano-biocatalysts in the treatment of biomass materials prior to the step of hydrolysis, is very promising to turn around the whole approach [78,79]. Additionally, different nanomaterials require different concentration towards the optimum yield achievement. One of the main problems connected to this method is the cost of the biocatalyzing substance, which has been addressed through the manufacturing of nanobio-catalysts. One of the greatest motivations nowadays is the necessity for photo-digestion chambers that use visible light photoactive metal oxides, in order to enhance the amount of $\mathrm{H}_{2}$ generated and as a result, increase of $\mathrm{CH}_{4}$ yield.

Exposure of woody biomass substrates to air/oxygen along with hydrogen peroxide $\left(\mathrm{H}_{2} \mathrm{O}_{2}\right)$ or water at temperature above $120{ }^{\circ} \mathrm{C}$ for $30 \mathrm{~min}$ is called wet oxidation. This method has been proposed to modify waste-water and soil regulation, and it seems to be appropriate for biomass of high lignin contents [80]. Temperature, oxygen pressure, and reaction time are the factors influencing the effectiveness of this method. At temperature $>165^{\circ} \mathrm{C}$, moisture behaves as an acid and contributes to hydrolysis. More specifically, lignin tends to become oxidized and hemicelluloses to be disintegrated into smaller monomers, whereas the impact on cellulose is much less extended. As evidenced, the incorporation of sodium carbonate and alkaline peroxide increases hemicelluloses depolymerization, limits the reaction temperature, and decreases the inhibitors generation. The natural combustion of pure $\mathrm{O}_{2}$ and extremely high expense of $\mathrm{H}_{2} \mathrm{O}_{2}$ are the main drawbacks of this method limiting its large-scale application [23].

Biological pretreatment is an environmentally friendly, since it requires less energy, and effective method. It involves the presence of microorganisms, enzymes, or a mixture of them to increase the biological decomposition of biomass substrates and as a result, improve the biogas yields. The microorganisms introduced degrade the lignin network of the biomass substrate towards biogas production. There are several microbes in the nature that depolymerize cellulose or hemicelluloses and can be effectively used as a pre-treatment of biomass. White, brown, and soft-rot fungi, enzymes and bacteria that highly degrade lignin as well as hemicelluloses and certain percentage of cellulose can be used in biomass degradation. However, a long incubation period is required (about 30 days). White rot fungi are able to form enzymes that acquire high hydrolytic action towards lignocellulosic substrates degradation, such as lignin peroxidase, lacasse, and manganese peroxidase. White-rot fungi that degrade lignin have been used mainly for biological treatment [23]. The effectiveness of bio-deposition with anaerobic fungus Orpinomyces sp. was evaluated in $\mathrm{AD}$ formulations using lignocellulosic substrate. Fungal infection improved $\mathrm{CH}_{4}$ yield by $14-35 \%$ during $\mathrm{AD}$ of a selected wheat crops variety. A more efficient fermentation process in biodegradable digesters was characterized by a relatively higher abundance of Synergistetes, which is mainly represented by the genus Anaerobaculum. In contrast, the synthesis of methanogens was not modified and the majority of methanogens corresponds to Methanosarcina [81].

Enzyme pretreatment is a technique even faster than fungal treatment, since the enzymes are eve smaller than the microorganisms and act in only few hours. They have great mobility and solubility; there is a close relation between biomass and enzymes [82]. The cellulose hydrolysis in this case is achieved using enzymes that have endogluconase, exogluconase, and $\beta$-glucosidase properties, whereas hemicelluloses degradation requires a lot of enzymes that include endo-xylanase, $\alpha$-glucuronidase, etc. Since this method involves additional steps of sterilization and the cost of enzymes is quite high, this method has not been used in the industrial level so far due to the high cost.

Ensiling is a pretreatment method involving the action of microoragnisms, commonly used to store wet biomass before processing. Specifically, soluble holocellulose is converted into acids (acetic, butyric, lactic, propionic, etc.) by the action of microorganisms. The $\mathrm{pH}$ is usually below 4 throughout this process, which hinders the microorganisms' growth, while 
the conversion of biomass is benefited. This method could increase biogas production under particular conditions [83]. Lignocellulosic biomass type, particle dimensions, moisture content, etc., highly affect the efficiency of this technique. A benefit coming from this technique is that biomass could be utilized throughout the whole year beyond limitations raised by cultivation periods.

Bacteria with strong hydrolytic action have been employed as a biological pre-treatment method. Pseudomonas, Escherichia coli, Salmonella, etc., are species with the ability to disintegrate cellulose and hemicelluloses. According to literature, methane yield has been increased up to $158.7 \%$, when nine bacterial strains with endoglucanase properties were employed towards the decomposition of microalgae substrate. An increase of $38 \%$ of methane yield was demonstrated when a microbial mixture of great cellulolytic action was used for the biodigestion of maize substrate [23].

Bioaugmentation is another process that could be performed to incorporate specific microorganisms into the digester in order to improve the steps of AD. Specifically, it enhances the start-up of a digester, the performance of the whole process, or improves the depolymerization action of a mixture of microorganism species. It is an effective technique that does not include previous steps of treatment, therefore the process is simplified and highly cost-effective. Furthermore, this method has been employed in cases where the biogas digesters need to be recovered after malfunctioning potentially because of high volatile fatty acids gathering or because of a high charging rate. Concerning the utilization of this method to increase biogas yield coming from lignocellulosic substrates, several microorganism species have been evaluated separately or in a mixture of species that present high biomass depolymerization action [84].

Biological pre-treatment methods demonstrate also some drawbacks, such as longer treatment duration, particular microorganisms' growth conditions, larger space and mass (holocellulose) loss. The enormous cost of enzymes and microorganisms such as fungi, bacteria, etc., is a crucial factor that determines the feasibility, the economics and perspectives of these methods in biomethanation [23].

The efficiency of pretreatment varies depending on the biomass type, and pretreatment methods could be generally classified into physical, chemical, physicochemical, and biological methods, which include methods based on enzymes and fungi [85]. All these methods are characterized by some advantages and limitations, in case of fungi concerning their difficulty in withstanding the extreme conditions. On the other hand, the bacterial metabolic mechanism can withstand the extreme changes in the media during depolymerization of lignin residues and its metabolites because of the environmental adaptability and bio-chemical flexibility of bacteria. Generally, there are only a few studies in this direction of lignin disintegration and valorization. Bacterial species such as the Streptomyces, Pseudomonas, Athrobacter, and Rhodococcus have been examined in the breakdown ability level of lignin using extracellular enzymes [85-87]. The most crucial advantages and drawbacks of different pretreatment techniques concerning the lignocellulosic biomass depolymerization towards the methane production are presented in Table 3.

Several physical, chemical, biological, those utilizing nanoparticles, thermal as well as combinations of pretreatment techniques that have stood out in previous years to overpower the limitations of biomethanation of lignocellulosic biomass materials. It could be stated that generally, in all cases of these pretreatments, they demonstrate variant benefits and difficulties, and the optimum choice seems to be the rational conjugation of biomass chemistry and pretreatment technique, in a way that the objective of pretreatment is being achieved. Appropriate choice of treatment may enhance the effectiveness of biomethanation pretreatment practices. The consumed energy for each of these methods is another crucial factor [23]. Optimally, the selected pre-treatment method requires low investment cost, low energy and in parallel, causes great improvement both in terms of feedstock degradation, decreasing the recalcitrance of lignin and other constituents, and biogas yield increase. Some of these pretreatment methods tend to improve the biomass substrate depolymerization rate, though provide only a very low effect on biomethanation production. 
Table 3. Advantages and limitations of the most commonly used pre-treatment methods concerning the lignocellulosic biomass depolymerization $[85,88,89]$.

\begin{tabular}{|c|c|c|}
\hline Pretreatments Methods & Merits & Drawbacks \\
\hline Physical Pretreatments & $\begin{array}{l}\text { 1. Increase the surface area of substrate by } \\
\text { decreasing the particle dimensions } \\
\text { 2. Improve the accessibility of the substrate } \\
\text { 3. Increase its susceptibility to microbial and } \\
\text { enzyme attacks }\end{array}$ & - \\
\hline $\begin{array}{l}\text { Mechanical Pretreatments } \\
\text { Milling/Grinding }\end{array}$ & $\begin{array}{l}\text { 1. Reduce the cellulose crystallinity and } \\
\text { particle size } \\
\text { 2. Increase surface area, and is easy to } \\
\text { substrate management } \\
\text { 3. Disruption of hydrogen bonds and } \\
\text { cellulose crystallinity } \\
\text { 4. Increase surface area } \\
\text { 5. Fast heat transfer } \\
\text { 6. Short reaction time }\end{array}$ & $\begin{array}{l}\text { 1. High energy demand } \\
\text { 2. Scalability issues }\end{array}$ \\
\hline
\end{tabular}

\begin{tabular}{|c|c|c|}
\hline \multicolumn{3}{|l|}{ Chemical Pretreatments } \\
\hline Acid & $\begin{array}{l}\text { 1. Hydrolysis of hemicelluloses and } \\
\text { alteration of structure }\end{array}$ & $\begin{array}{l}\text { 1. High cost for equipment and acids } \\
\text { 2. Formation of inhibitors }\end{array}$ \\
\hline Alkali & $\begin{array}{l}\text { 1. Hydrolysis of Lignin } \\
\text { 2. Alteration of cellulose structure }\end{array}$ & $\begin{array}{l}\text { 1. High costs of alkali } \\
\text { 2. Formation of inhibitors }\end{array}$ \\
\hline Oxidative & 1. Removal of hemicelluloses and lignin & $\begin{array}{l}\text { 1. High cost of chemicals } \\
\text { 2. Formation of inhibitors }\end{array}$ \\
\hline Organo solvents & $\begin{array}{l}\text { 1. Solubilization of lignin and hemicelluloses } \\
\text { and cellulose }\end{array}$ & High cost of solvent \\
\hline \multicolumn{3}{|c|}{ Physico-chemical Pretreatments } \\
\hline Extrusion & $\begin{array}{l}\text { 1. Destruction of cellulose structure } \\
\text { 2. Increase surface area }\end{array}$ & High energy consumption \\
\hline Hydrothermal & $\begin{array}{l}\text { 1. Hydrolysis of Lignin and hemicelluloses } \\
\text { 2. Destruction of cellulose structure }\end{array}$ & $\begin{array}{l}\text { 1. High water consumption } \\
\text { 2. High energy input }\end{array}$ \\
\hline Steam explosion & $\begin{array}{l}\text { 1. Hydrolysis of Lignin and hemicelluloses } \\
\text { 2. Destruction of cellulose crystallinity }\end{array}$ & $\begin{array}{l}\text { 1. High energy demand } \\
\text { 2. Recalcitrant compounds formation }\end{array}$ \\
\hline \multicolumn{3}{|l|}{ Biological Pretreatments } \\
\hline Microbial & $\begin{array}{l}\text { 1. Hydrolysis of Lignin and hemicelluloses } \\
\text { 2. Alteration of cellulose structure } \\
\text { 3. No any inhibitory compound formation } \\
\text { 4. Low energy consumption }\end{array}$ & $\begin{array}{l}\text { 1. The process is slow } \\
\text { 2. There carbon loss } \\
\text { 3. Necessity of a large sterile area }\end{array}$ \\
\hline Enzymes & $\begin{array}{l}\text { 1. Alteration of cellulose structure } \\
\text { 2. Delignification } \\
\text { 3. Partial hydrolysis of hemicellulose } \\
\text { 4. The process is fast } \\
\text { 5. The energy demand is low }\end{array}$ & $\begin{array}{l}\text { 1. The cost of enzymes is high } \\
\text { 2. Continuous addition may be required }\end{array}$ \\
\hline
\end{tabular}

\subsection{Combination of Pre-Treatments}

The application of combined pretreatments has been suggested by several studies so far. For example, the combination of alkaline with enzymatic pretreatment has been evaluated using as a substrate cassava peels, and it seems to improve biomethanation yield. Combination of different pretreatments was studied by [90], namely a combination of organosolv, dilute acid, and cellulolytic enzymes pre-treatment methods, which recorded the highest biogas yield compared to the action of these methods applied separately. A combination of steam explosion, particle dimensions decrease, and $\mathrm{NaOH}$ treatments was investigated on miscanthus substrate in the direction of biogas optimization, and it was 
found the optimum option improving methane released by $57 \%$ when compared with the untreated substrate. A combination of acetic acid and steam explosion $\left(180{ }^{\circ} \mathrm{C}, 17.45 \mathrm{~min}\right.$ reaction time) pre-treatments was applied to sugarcane bagasse substrate and improved biogas yield by $91.88 \%$, compared to untreated biomass. The application of a combination of alkali activation and mild thermal treatment in order to enhance methane production coming from residual biomass of activated sludge was experimented, providing optimistic results of improvement [91].

In their study, Navarro et al. [92] presented the large-scale pretreatment potential of simultaneous enzymatic saccharification and comminution (SESC) method of AD for various wood lignocellulosic materials to generate methane, as well as unmodified lignin. Moreover, biological and chemical analyses of the sludge were also implemented to strengthen the biodegradation of the SESC-treated woody substrate and determine the fate of lignin throughout the AD process. The results showed that SESC was successfully used as a pretreatment method of woody biomass in $\mathrm{AD}$ and is considered effective for large-scale $\mathrm{AD}$ of wood and other lignocellulosic materials. High yields through conversion of holocellulose of conifers and broadleaved species to $\mathrm{CH}_{4}$ were achieved. Biogas production from SESC-treated cedar bark was also accomplished in spite of the concerns about its toxicity to the sludge microorganisms and slurry yielded $224 \mathrm{~L}$ methane $/ \mathrm{kg}$ of cedar. The content of lignin in the sludge was confirmed, which is a significant by-product of combined SESC and $\mathrm{AD}$.

Moreover, Khan and Ahring [93] examined ways to transform the biorefinery lignin into an available form for AD process. They used as feedstock the waste after removing carbohydrates by wet explosion pretreatment at $190{ }^{\circ} \mathrm{C}$ and $7.5 \% \mathrm{O}_{2}$, followed by enzymatic hydrolysis. Lignin degradation was examined in the light of the diffusive methoxylations within the lignin network during WEt pretreatment. The chemical analysis of feedstock solid part and effluent after digestion was determined to understand which part of the raw material carbohydrates or lignin acid-soluble or insoluble fractions was transformed throughout the $\mathrm{AD}$ process. From the raw material, the holocellulose was removed using enzymatic hydrolysis under specific conditions $\left(190{ }^{\circ} \mathrm{C}\right.$ and $\left.7.5 \% \mathrm{O}_{2}\right)$. Then, in the residual solid Lignin " $\mathrm{A}$ " which consist of lignin, a second pretreatment $\left(220^{\circ} \mathrm{C}, 4 \% \mathrm{O}_{2}, \mathrm{NaOH}\right.$ $(0-2 \%)$ was implemented. Lignin "B" was pretreated without $\mathrm{NaOH}$. Lignin " $\mathrm{C}$ " was pretreated with $1 \% \mathrm{NaOH}$ and Lignin " $\mathrm{E}$ " with $2 \% \mathrm{NaOH}$. The $\mathrm{AD}$ was carried out at $52{ }^{\circ} \mathrm{C}$ and $70 \%$ of each lignin was mixed with $30 \%$ of clarified manure. The results showed that methoxylation of lignin increased with lignin depolymerization. Furthermore the incorporation of $\mathrm{NaOH}$ and $\mathrm{O}_{2}$ improved the degradation of lignin and eventually, a total of $56.3 \%$ lignin was converted into methane. Lignin yielded $106.2 \%$ more $\mathrm{CH}_{4}$ compared to clarified manure.

Several studies have been implemented dealing with the performance of pretreatment techniques to improve the degradation of biomass substrates and $\mathrm{CH}_{4}$ release. However, the higher the number of pre-treatment methods applied to the substrate, the higher the cost of biogas. Therefore, simple, sustainable, effective and low-cost pretreatment methods should be further investigated in the coming years. When different techniques or chemicals were used to a specific biomass material, the results obtained were not the same [94]. The utilization of agricultural and forest wastes rather than more conventional biomass substrates (crop species with high starch content) can be proven to be a preferable economical and highly available source of glucose for the generation of liquid or gas bio-fuels intended for transportation and other energy applications [23]. Nevertheless, the structure and anatomical characteristics of lignocellulosic residues still exhibit limitations, as a result of their low bio-accessibility. The substrate pretreatment and the inner structure of the biomass material are crucial to the hydrolysis success.

It is quite difficult to specify the pretreatment techniques of the biomass raw material that would ensure the best yields. Among a great variety of substrates and pre-treatment methods, the optimum method could be selected, though an effective and economically viable method that fulfills the requirements of industry scale has not been discussed thor- 
oughly so far [23]. The selection of pretreatment technique should be based on the chemical composition, physical and anatomical characteristics of the biomass substrate material. The main challenge is to combine the improvement of organic material accessibility, biodigestion, sugars release and to still maintain the mass of the substrate during the process avoiding matter losses that could increase the cost and avoiding also the generation of inhibitory substances of biodigestion during the pre-treatment application.

To fulfill a techno-economic potential of processing biomass substrates, the approach of integrated bio-refineries, in which several bio-products can be created in the same platform could be a brilliant and beneficial approach. Hydrogen, bio-ethanol, or biodiesel refinery could be incorporated into biogas refinery, making materials pretreatment more economical and incorporating one or more valuable streams into the biorefinery. That would also promote substrate treatment industrially to a large extent. Residues coming from this additional refinery could be the raw material for biomethane yield, therefore limiting the pretreatment [23]. The double stage process of hydrogen production before $\mathrm{CH}_{4}$ generation would be more productive than the single stage of $\mathrm{CH}_{4}$ production. The utilization of wastes coming from amino acids and lipids extraction process is indicated to increase the biomethane yields from biomass substrates, because the residues would have been subjected treatment prior to AD. One of the most significant challenges is the exploitation of the waste materials of AD procedure. The utilization of such residues in integrated biorefineries would limit both the challenges of pretreatment of biomass throughout the biogas generation and the challenge of residual mass management. It is required to assess such techniques commercially and identify the optimum techniques of biomass pretreatment for commercial purposes [20].

\subsection{Biogas Purification Technologies-Applications}

Generally, biogas presents low energy content in its original state. After the biogas production, biogas can be purified and upgraded to raise its calorific value by around $15 \%$ and its potential application range as well. The upgrade of biogas is undoubtedly required for its utilization in transportation and industrial fields [13]. It is a practice widely followed in countries such as Switzerland and Sweden [95]. Current biogas upgrading technologies are considered relatively mature and include, among others, cryogenic separation, physical/chemical absorption, membrane separation, amine scrubbing, water scrubbing, pressure swing adsorption, etc. Each of them displays variant merits and drawbacks concerning energy consumption, required solvents, as well as financial investments [13]. Most of these techniques are based on physical properties such as cryogenic separation, which exploits the difference in the condensation temperatures of $\mathrm{CH}_{4}$ and $\mathrm{CO}_{2}$ to isolate and remove them, thus producing a liquid rich in bio-methane. As regards some other techniques, the impurities are abolished considering the equilibrium established between liquid and gas phases at variant pressures, such as in physical absorption and water scrubbing, in which $\mathrm{CO}_{2}$ solubility in organic solvents or water is exploited as a separation mechanism [23].

Of course, the use of these kinds of solvents increases the operating and maintenance costs of relative plants between 1.05 and 1.42 euro cent $/ \mathrm{kWh}$, which could influence the final cost of $\mathrm{CH}_{4}$, as well as the process suitability. Generally, water scrubbing is the typically employed technique industrially, due to the lower biogas prices and satisfying purity achieved ( $82-99 \%)$, even though the consumed power is usually increased compared to the rest techniques that have been reported [13].The upgraded biogas can be utilized as an important renewable energy source, but in parallel, it can be used as a source of chemicals, using methane as feedstock. Biogas can be altered into syngas, which is the source of variant fuels (e.g., methanol, dimethyl ether, hydrogen). Aiming at this transformation, among other practices, the most common is the steam reforming [20]. Furthermore, through the Fischer-Tropsch process, which is a much complicated and strictly controlled process, specific conditions can be established in order the syngas or $\mathrm{CH}_{4}$ to be incorporated in catalytic systems operations to obtain methanol, hydrocarbon 
compounds like olefins, paraffins, etc., or several other final products [9]. Different studies have worked on enhancing catalytic systems, also involving it in biological systems. In this direction, so far some progress has been reported in the field of lactate, biodiesel, and biopolymers generation [23].

\section{Conclusions}

Anaerobic digestion opens a new path for the biochemical utilization of different wastes to produce energy and a nutrient-rich material, which depending on its quality and soil condition, could be utilized as a valuable fertilizer. The method of AD is able to utilize materials of low value and negative cost of residual character, such as the highly available lignocellulosic wastes coming from forest, agricultural or marine biomass utilization processes, in order to convert them through a mature technique, low-demanding infrastructures and quite low-level of required investment, into directly usable energy. Lignin depolymerization constitutes a great challenge for the establishment of full scale process for AD of lignin waste. Pre-treatment of biomass substrates in an affordable, efficient and sustainable manner constitutes a great motivation for AD the coming years. Pre-treatment methods, such as thermo-chemical, hydrothermal, acid hydrolysis, pyrolysis, gasification, etc., contribute to the addressing of this problem. During the pre-treatment method, attention should be paid to avoid the formation of inhibitors of digestion that would decrease the biomass production. Based on the so far examined biomass substrates and methods/technologies, an appropriate method could be applied, though an effective and economically viable method that fulfills the requirements of industrial application has not been identified so far. Chemical pretreatments are widely applied because of the effectiveness, increased biogas production, even though they are noxious to the environment. Typically, a combination of two or multiple pretreatment methods seems to be more effective and economic, thus a preferable solution, compared to mono-treatments. Therefore, AD systems are immensely expanding globally and especially in Europe, meeting the high demands of humans for clean energy. Since the lignocellulosic materials are also an attractive feedstock for industries of pulp, paper, fiberboards, particleboards, and other wood-based products, as well as the solid biofuels (pellets, briquettes), a gradual lack of suitable substrates for digestion is expected to come in the near future, and new substrates will be investigated, in materials that are considered at present either problematic or difficult to utilize.

Author Contributions: Conceptualization, V.K.; methodology, V.K.; investigation, P.T.; writingoriginal draft preparation, P.T.; writing-review and editing, V.K.; visualization, V.K.; supervision, V.K. All authors have read and agreed to the published version of the manuscript.

Funding: This research received no external funding.

Institutional Review Board Statement: Not applicable.

Informed Consent Statement: Not applicable.

Conflicts of Interest: The authors declare no conflict of interest.

\section{References}

1. Venkateswara, R.P.; Baral, S.S.; Dey, R.; Mutnuri, S. Biogas generation potential by anaerobic digestion for sustainable energy development in India. Renew. Sustain. Energy Rev. 2010, 14, 2086-2094. [CrossRef]

2. Barrera, E.L.; Spanjers, H.; Dewulf, J.; Romero, O.; Rosa, E. The sulfur chain in biogas production from sulfate-rich liquid substrates: A review on dynamic modeling with vinasse as model substrate. J. Chem. Technol. Biotechnol. 2013, 88, 1405-1420. [CrossRef]

3. De Souza, S.N.; Santos, R.F.; Fracaro, G.P. Potential for the production of biogas in alcohol and sugar cane plants for use in urban buses in the Brazil. In Proceedings of the World Renewable Energy Congress-Sweden, Linköping, Sweden, 8-13 May 2011; Linköping University Electronic Press: Linköping, Sweden; p. 418. [CrossRef]

4. Pazuch, F.A.; Nogueira, C.E.C.; Souza, S.N.M.; Micuanski, V.C.; Friedrich, L.; Lenz, A.M. Economic evaluation of the replacement of sugar cane bagasse by vinasse, as a source of energy in a power plant in the state of Paraná, Brazil, Renew. Sustain. Energy Rev. 2017, 76, 1-1578. [CrossRef] 
5. Terzopoulou, P.; Kamperidou, V. Chemical characterization of Wood and Bark biomass of the invasive species of Tree-of-heaven (Ailanthus altissima (Mill.) Swingle), focusing on its chemical composition horizontal variability assessment. Wood Mater. Sci. Eng. 2021, 1-9. [CrossRef]

6. Rittmann, B. Opportunities for renewable bioenergy using microorganisms. Biotechnol. Bioeng. 2008, 100, 203-212. [CrossRef] [PubMed]

7. Filippou, I. Chemistry and Chemical Technology of Wood; Giahoudi-Giapouli Publications: Thessaloniki, Greece, $2014 ;$ p. 357.

8. Kamperidou, V.; Lykidis, C.; Barmpoutis, P. Utilization of wood and bark of fast-growing hardwood species in energy production. J. For. Sci. 2018, 64, 1-7. [CrossRef]

9. Okolie, J.A.; Mukherjee, A.; Nanda, S.; Dalai, A.K.; Kozinski, A.J. Next-generation biofuels and platform biochemicals from lignocellulosic biomass. Int. J. Energy Res. 2021, 45, 14145-14169. [CrossRef]

10. Kelleher, B.P.; Leahy, J.J.; Henihan, A.M.; O’Dwyer, T.F.; Sutton, D.; Leahy, M.J. Advances in poultry litter disposal technology-A review. Bioresour. Technol. 2002, 83, 27-36. [CrossRef]

11. Faaij, A. Modern Biomass Conversion Technologies. Mitig. Adapt. Strat. Glob. Chang. 2006, 11, 343-375. [CrossRef]

12. Stefanidou, M.; Kamperidou, V.; Konstantinidis, A.; Koltsou, P.; Papadopoulos, S. Use of Posidonia oceanica fibres in lime mortars. Constr. Build. Mater. 2021, 298, 123881. [CrossRef]

13. Solarte-Toro, J.C.; Chacón-Pérez, Y.; Cardona-Alzate, C.A. Evaluation of biogas and syngas as energy vectors for heat and power generation using lignocellulosic biomass as raw material. Electron. J. Biotechnol. 2018, 33, 52-62. [CrossRef]

14. Xu, N.; Liu, S.; Xin, F.; Zhou, J.; Jia, H.; Xu, J.; Jiang, M.; Don, W. Biomethane Production from Lignocellulose: Biomass Recalcitrance and Its Impacts on Anaerobic Digestion. Front. Bioeng. Biotechnol. 2019, 7, 191. [CrossRef]

15. Frigon, J.C.; Mehta, P.; Guiot, S.R. Impact of mechanical, chemical and enzymatic pre-treatments on the methane yield from the anaerobic digestion of switchgrass. Biomass Bioenerg. 2011, 36, 1-11. [CrossRef]

16. Mustafa, A.M.; Poulsen, T.G.; Sheng, K. Fungal pretreatment of rice straw with pleurotus ostreatus, and trichoderma reesei, to enhance methane production under solid-state anaerobic digestion. Appl. Energy 2016, 180, 661-671. [CrossRef]

17. Herrmann, C.; Idle, C.; Heiermann, M. Biogas crops grown in energy crop rotations: Linking chemical composition and methane production characteristics. Bioresour. Technol. 2016, 206, 23-35. [CrossRef] [PubMed]

18. Mulat, D.G.; Dibdiakova, J.; Horn, S.J. Microbial biogas production from hydrolysis lignin: Insight into lignin structural changes. Biotechnol. Biofuels 2018, 11, 61. [CrossRef]

19. Schroyen, M.; Vervaeren, H.; Vandepitte, H.; Van Hulle, S.W.; Raes, K. Effect of enzymatic pretreatment of various lignocellulosic substrates on production of phenolic compounds and biomethane potential. Bioresour. Technol. 2015, 192, 696-702. [CrossRef]

20. Sun, J.; Zhang, L.; Loh, K. Review and perspectives of enhanced volatile fatty acids production from acidogenic fermentation of lignocellulosic biomass wastes. Bioresour. Bioprocess. 2021, 8, 68. [CrossRef]

21. Rezania, S.; Din, M.F.M.; Mohamad, S.E.; Sohaili, J.; Taib, S.M.; Yusof, M.B.M.; Kamyab, H.; Darajeh, N.; Ahsan, A. Review on Pretreatment Methods and Ethanol Production from Cellulosic Water Hyacinth. BioResources 2017, 12, 2108-2124. [CrossRef]

22. Zhang, Y.; Hu, J. Development of Chinese character-writing program for mobile devices. In Handbook of Mobile Teaching and Learning; Zhang, Y., Cristol, D., Eds.; Springer: Berlin/Heidelberg, Germany, 2018; pp. 1-15.

23. Olatunji, K.O.; Ahmed, N.A.; Ogunkunle, O. Optimization of biogas yield from lignocellulosic materials with different pretreatment methods: A review. Biotechnol. Biofuels 2021, 14, 159. [CrossRef] [PubMed]

24. Soltanian, S.; Aghbashlo, M.; Almasi, F.; Hosseinzadeh-Bandbafha, H.; Nizami, A.-S.; Ok, Y.S.; Lam, S.S.; Tabatabaei, M. A critical review of the effects of pretreatment methods on the exergetic aspects of lignocellulosic biofuels. Energy Convers. Manag. 2020, 212, 112792. [CrossRef]

25. REN. Renewables Global Status Report, Renewable Energy Policy Network for the 21st Century. 2016. Available online: http:/ / www.ren21.net/resources / publications / (accessed on 15 July 2021).

26. European Statistics. Available online: http:/ / ec.europa.eu/eurostat (accessed on 1 July 2017).

27. EBA (European Biogas Association). Annual Statistical Report. 2016. Available online: https://european-biogas.eu (accessed on 15 July 2021).

28. IRENA (International Renewable Energy Agency). Renewable Capacity Statistics 2016, 2017; International Renewable Energy Agency: Abu Dhabi, United Arab Emirates, 2017.

29. IEA. International Energy Agency Medium-Term Renewable Energy Market Report 2016. In Market Analysis and Forecasts to 2021; IEA: Paris, France, 2016.

30. Vögeli, Y.; Lohri, C.R.; Gallardo, A.; Diener, S.; Zurbrügg, C. Anaerobic Digestion of Biowaste in Developing Countries: Practical Information and Case Studies; Swiss Federal Institute of Aquatic Science and Technology (Eawag): Dübendorf, Switzerland, 2014. [CrossRef]

31. Scarlat, N.; Dallemand, J.F.; Monforti-Ferrario, F.; Banja, M.; Motola, V. Renewable energy policy framework and bioenergy contribution in the European union-An overview from national renewable energy action plans and progress reports. Renew. Sustain. Energy Rev. 2015, 51, 969-985. [CrossRef]

32. Pavlostathis, S.G.; Giraldo-Gomez, E. Kinetics of anaerobic treatment: A critical review. Crit. Rev. Environ. Control. 1991, 21, 411-490. [CrossRef]

33. Rogakou, S. Utilization of Biogas for Energy Production and Possibility of Feedback in the Natural Gas Network. Ph.D. Thesis, School of Electronic and Computer Engineering, Technical University of Crete, Chania, Greece, 2012. 
34. U.S. EPA. United States Environmental Protection Agency. AgStar Program Biogas Recovery in the Agriculture Sector; U.S. EPA: Washington, DC, USA, 2017.

35. Hatzitakis, A. Effect of Homogeneous Photocatalytic Oxidation on the Increase of Biogas Production and the Reduction of the Liquid Load of Liquid Waste. Master's Thesis, Aristotle University of Thessaloniki (AUTh), School of Sciences, Department of Chemistry, Thessaloniki, Greece, 2008.

36. Vavilin, V.A.; Lokshina, L.Y.; Flotats, X.; Angelidaki, I. Anaerobic digestion of solid material: Multidimensional modeling of continuous-flow reactor with non-uniform influent concentration distributions. Biotechnol. Bioeng. 2007, 97, 354-366. [CrossRef] [PubMed]

37. Chynoweth, D.; Haley, P.; Owens, J.; Teixeira, A.A.; Welt, B.; Rich, E.; Townsend, T.; Choi, H. Anaerobic Digestion for Reduction and Stabilization of Organic Solid Wastes During Space Missions: Laboratory Studies; SAE International: Warrendale, PA, USA, 2001. [CrossRef]

38. Ogunkunle, O.; Ahmed, N.A.; Olatunji, K.O. Biogas Yields Variance from Anaerobic Co-Digestion of Cow Dung with Jatropha Cake under Mesophilic Temperatures. J. Phys. Conf. Ser. 2019, 1378, 032060. [CrossRef]

39. Atelge, M.R.; Krisa, D.; Kumar, G.; Eskicioglu, C.; Nguyen, D.D.; Chang, S.W.; Atabani, A.E.; Al-Muhtaseb, A.H.; Unalan, S. Biogas Production from Organic Waste: Recent Progress and Perspectives. Waste Biomass Valor. 2020, 11, 1019-1040. [CrossRef]

40. Latif, M.A.; Mehta, C.M.; Batstone, D.J. Influence of low $\mathrm{pH}$ on continuous an aerobic digestion of waste activated sludge. Water Res. 2017, 113, 42-49. [CrossRef] [PubMed]

41. Börjesson, P.; Mattiasson, B. Biogas as a Resource-Efficient Vehicle Fuel. Trends Biotechnol. 2008, 26, 7-13. [CrossRef]

42. Aziz, A.; Izzah Hamna, N.; Marlia, H.M.; Ali, M.; Yasreen, M. Sustainable biogas production from agrowaste and effluents-A promising step for small-scale industry income. Renew. Energy 2019, 132, 363-369. [CrossRef]

43. Saelee, K.; Yingkamhaeng, N.; Nimchua, T.; Sukyai, P. An environmentally friendly xylanase-assisted pretreatment for cellulose nanofibrils isolation from sugarcane bagasse by high-pressure homogenization. Ind. Crop. Prod. 2016, 1, 149-160. [CrossRef]

44. Jin, S.; Zhang, G.; Zhang, P.; Fan, S.; Li, F. High-pressure homogenization pretreatment of four different lignocellulosic biomass for enhancing enzymatic digestibility. Bioresour. Technol. 2015, 1, 270-274. [CrossRef] [PubMed]

45. Maroušek, J. Finding the Optimal Parameters for the Steam Explosion Process of Hay. Rev. Técnica. La Fac. Ing. Univ. Del Zulia. 2012, 35, 170-178. Available online: https:/ / www.researchgate.net/publication/297295742_Finding_the_optimal_parameters_ for_the_steam_explosion_process_of_hay (accessed on 10 June 2021).

46. Yeow, S.K.; Peng, W.L. Application of ultrasound pretreatment for sludge digestion. In Biogas Production: Pretreatment Methods in Anaerobic Digestion; Mudhoo, A., Ed.; Wiley: Hoboken, NJ, USA, 2012; pp. 91-136. [CrossRef]

47. Eisenmenger, M.J.; Reyes-De-Corcuera, J.I. High pressure enhancement of enzymes: A review. Enzyme Microb. Technol. 2009, 45, 331-347. [CrossRef]

48. Luengo, E.; Martínez, J.M.; Coustets, M.; Álvarez, I.; Teissié, J.; Rols, M.P.; Raso, J. A comparative study on the effects of millisecond- and microsecondpulsed electric field treatments on the permeabilization and extraction of pigments from Chlorella vulgaris. J. Membr. Biol. 2015, 248, 883-891. [CrossRef]

49. Kamperidou, V.; Barboutis, I.; Vasileiou, V. Effect of thermal treatment on colour and hygroscopic properties of poplar wood. In Proceedings of the 23rd International Scientific Conference: Wood is Good-With Knowledge and Technology to a Competitive Forestry and Wood Technology Sector, Proceedings, Zagreb, Croatia, 12 October 2012; pp. 59-67.

50. Wang, J.; Yue, Z.B.; Chen, T.H.; Peng, S.C.; Yu, H.Q.; Chen, H.Z. Anaerobic digestibility and fiber composition of bulrush in response to steam explosion. Bioresour. Technol. 2010, 101, 6610-6614. [CrossRef] [PubMed]

51. Vassiliou, V.; Barboutis, I.; Kamperidou, V. Strength of Corner and Middle Joints of Upholstered Furniture Frames Constructed with Black Locust and Beech Wood. Wood Res. 2016, 61, 495-504. Available online: http:/ /www.centrumdp.sk/wr/201603/15.pdf (accessed on 1 April 2021).

52. Kamperidou, V. Chemical and structural characterization of poplar and black pine wood exposed to short thermal modification. Drv. Ind. 2021, 72, 155-167. [CrossRef]

53. Barboutis, I.; Kamperidou, V. Impact of heat treatment on the quality of Tree-of-heaven wood. Drv. Ind. 2019, 70, 351-358. [CrossRef]

54. Taherzadeh, M.J.; Karimi, K. Pretreatment of lignocellulosic wastes to improve ethanol and biogas production: A review. Int. J. Mol. Sci. 2008, 9, 1621-1651. [CrossRef]

55. Gedye, R.; Smith, F.; Westaway, K.; Ali, H.; Baldisera, L.; Laberge, L.; Rousell, J. The use of microwave ovens for rapid organic synthesis. Tetrahedron Lett. 1986, 27, 279-282. [CrossRef]

56. Li, H.; Qu, Y.; Yang, Y.; Chang, S.; Xu, J. Microwave irradiation-A green and efficient way to pretreat biomass. Bioresour. Technol. 2016, 199, 34-41. [CrossRef] [PubMed]

57. Salema, A.A.; Ani, F.N.; Mouris, J.; Hutcheon, R. Microwave dielectric properties of Malaysian palm oil and agricultural industrial biomass and biochar during pyrolysis process. Fuel Process. Technol. 2017, 1, 164-173. [CrossRef]

58. Choudhary, R.; Umagiliyage, A.L.; Liang, Y.; Siddaramu, T.; Haddock, J.; Markevicius, G. Microwave pretreatment for enzymatic saccharification of sweet sorghum bagasse. Biomass Bioenergy 2012, 1, 218-226. [CrossRef]

59. Koyama, M.; Yamamoto, S.; Ishikawa, K.; Ban, S.; Toda, T. Inhibition of anaerobic digestion by dissolved lignin derived from alkaline pre-treatment of an aquatic macrophyte. Chem. Eng. J. 2017, 1, 55-62. [CrossRef] 
60. Taherdanak, M.; Zilouei, H. Improving biogas production from wheat plant using alkaline pretreatment. Fuel 2014, 115, 714-719. [CrossRef]

61. Marzialetti, T.; Valenzuela Olarte, M.B.; Sievers, C.; Hoskins, T.J.C.; Agrawal, P.K.; Jones, C.W. Dilute acid hydrolysis of loblolly pine: A comprehensive approach. Ind. Eng. Chem. Res. 2008, 47, 7131-7140. [CrossRef]

62. Xiao, W.; Clarkson, W.W. Acid solubilization of lignin and bioconversion of treated newsprint to methane. Biodegradation 1997, 8 , 61-66. [CrossRef]

63. Monlau, F.; Barakat, A.; Trably, E.; Dumas, C.; Steyer, J.P.; Carrère, H. Lignocellulosic materials into biohydrogen and biomethane: Impact of structural features and pretreatment. Crit. Rev. Environ. Sci. Technol. 2013, 43, 260-322. [CrossRef]

64. Ramakrishna, T.R.B.; Nalder, T.D.; Yang, W.; Marshall, S.N.; Barrow, C.J. Controlling enzyme function through immobilisation on graphene, grapheme derivatives and other two dimensional nanomaterials. J. Mater. Chem. B R Soc. Chem. 2018, 6, 3200-3218. [CrossRef]

65. Alvira, P.; Tomás-Pejó, E.; Ballesteros, M.; Negro, M.J. Pretreatment technologies for an efficient bioethanol production process based on enzymatic hydrolysis: A review. Bioresour. Technol. 2010, 101, 4851-4861. [CrossRef]

66. Cardeña, R.; Moreno, G.; Bakonyi, P.; Buitrón, G. Enhancement of methane production from various microalgae cultures via novel ozonation pretreatment. Chem. Eng. J. 2017, 1, 948-954. [CrossRef]

67. Zhu, J.Y.; Pan, X.J.; Wang, G.S.; Gleisner, R. Sulfite pretreatment (SPORL) for robust enzymatic saccharification of spruce and red pine. Bioresour. Technol. 2009, 100, 2411-2418. [CrossRef]

68. Baruaa, V.B.; Kalamdhada, A. Biogas Production from Water Hyacinth in a Novel Anaerobic Digester: A Continuous Study, 2019 Institution of Chemical Engineers; Elsevier, B.V.: Amsterdam, The Netherlands, 2019. [CrossRef]

69. Park, N.; Kim, H.Y.; Koo, B.W.; Yeo, H.; Choi, I.G. Organosolv pretreatment with various catalysts for enhancing enzymatic hydrolysis of pitch pine (Pinus rigida). Bioresour. Technol. 2010, 101, 7046-7053. [CrossRef] [PubMed]

70. Ostovareh, S.; Karimi, K.; Zamani, A. Efficient conversion of sweet sorghum stalks to biogas and ethanol using organosolv pretreatment. Ind. Crops Prod. 2015, 66, 170-177. [CrossRef]

71. Kim, K.H.; Hong, J. Supercritical $\mathrm{CO}_{2}$ pretreatment of lignocellulose enhances enzymatic cellulose hydrolysis. Bioresour. Technol. 2001, 77, 139-144. [CrossRef]

72. Pérez-Elvira, S.; Fdz-Polanco, M.; Plaza, F.I.; Garralón, G.; Fdz-Polanco, F. Ultrasound pre-treatment for anaerobic digestion improvement. Water Sci. Technol. 2009, 60, 1525-1532. [CrossRef]

73. Hyun Kim, T.; Nghiem, N.P.; Hicks, K.B.; Nghiem, N.P.; Hicks, K.B.; Kim, T.H. Pretreatment and fractionation of corn stover by soaking in ethanol and aqueous ammonia. Appl. Biochem. Biotechnol. 2009, 153, 171-179. [CrossRef]

74. Alizadeh, H.; Teymouri, F.; Gilbert, T.I.; Dale, B.E. Pretreatment of switchgrass by ammonia fiber explosion (AFEX). Appl Biochem Biotechnol Part A. Enzyme Eng. Biotechnol. 2005, 124, 1133-1141. [CrossRef]

75. Uppugundla, N.; Da Costa, S.L.; Chundawat, S.P.S.; Yu, X.; Simmons, B.; Singh, S.; Gao, X.; Kumar, R.; E Wyman, C.; E Dale, B.; et al. A comparative study of ethanol production using dilute acid, ionic liquid and AFEXTM pretreated corn stover. Biotechnol. Biofuels. 2014, 7, 1-14. [CrossRef] [PubMed]

76. Liu, L.; Chen, H. Enzymatic hydrolysis of cellulose materials treated with ionic liquid [BMIM] Cl. Chin. Sci. Bull. 2006, 51, 2432-2436. [CrossRef]

77. Taniguchi, M.; Suzuki, H.; Watanabe, D.; Sakai, K.; Hoshino, K.; Tanaka, T. Evaluation of pretreatment with Pleurotus ostreatus for enzymatic hydrolysis of rice straw. J. Biosci. Bioeng. 2005, 100, 637-643. [CrossRef]

78. Su, L.; Shi, X.; Guo, G.; Zhao, A.; Zhao, Y. Stabilization of sewage sludge in the presence of nanoscale zero-valent iron (nZVI): Abatement of odor and improvement of biogas production. J. Mater. Cycles Waste Manag. 2013, 15, 461-468. [CrossRef]

79. Kato, S.; Hashimoto, K.; Watanabe, K. Microbial Interspecies Electron Transfer via Electric Currents through Conductive Minerals. Proc. Natl. Acad. Sci. USA 2012, 109, 10042-10046. Available online: https:/ /www.pnas.org/content/109/25/10042 (accessed on 10 July 2021). [CrossRef] [PubMed]

80. Chaturvedi, V.; Verma, P. An overview of key pretreatment processes employed for bioconversion of lignocellulosic biomass into biofuels and value added products. 3 Biotech 2013, 3, 415-431. [CrossRef] [PubMed]

81. Akyol, Ç.; Ince, O.; Bozana, M.; Ozbayramb, E.G.; Ince, B. Fungal bioaugmentation of anaerobic digesters fed with lignocellulosic biomass: What to expect from anaerobic fungus Orpinomyces sp. Bioresour. Technol. 2019, 277, 1-10. [CrossRef]

82. Romero-Güiza, M.S.; Vila, J.; Mata-Alvarez, J.; Chimenos, J.M.; Astals, S. The role of additives on anaerobic digestion: A review. Renew. Sustain. Energy Rev. 2016, 58, 1486-1499. [CrossRef]

83. Franco, T.R.; Buffière, P.; Bayard, R. Ensiling for biogas production: Critical parameters. A review. Biomass Bioenergy 2016, 94 , 94-104. [CrossRef]

84. Martin-Ryals, A.; Schideman, L.; Li, P.; Wilkinson, H.; Wagner, R. Improving anaerobic digestion of a cellulosic waste via routine bioaugmentation with cellulolytic microorganisms. Bioresour. Technol. 2015, 189, 62-70. [CrossRef] [PubMed]

85. Kong, W.; Fu, X.; Wang, L.; Alhujaily, A.; Zhang, J.; Ma, F.; Zhang, X.; Yu, H. A novel 15622 and efficient fungal delignification strategy based on versatile peroxidase for lignocellulose 623 bioconversion. Biotechnol. Biofuels 2017, 10, 1-15. [CrossRef] [PubMed]

86. Beckham, G.T.; Johnson, C.W.; Karp, E.M.; Salvachúa, D.; Vardon, D.R. Opportunities 554 and challenges in biological lignin valorization. Curr. Opin. Biotechnol. 2016, 42, 40-53. [CrossRef] 
87. Pu, Y.; Hu, F.; Huang, F.; Davison, B.H.; Ragauskas, A.J. Assessing the molecular structure basis for biomass recalcitrance during dilute acid and hydrothermal pretreatments. Biotechnol Biofuels. 2013, 6, 15. [CrossRef]

88. Boladorodríguez, S.; Toquero, C.; Martínjuárez, J.; Travaini, R.; Garcíaencina, P.A. Effect of thermal, acid, alkaline and alkaline peroxide pretreatments on the biochemical methane potential and kinetics of the anaerobic digestion of wheat straw and sugarcane bagasse. Bioresour. Technol. 2016, 201, 182-190. [CrossRef] [PubMed]

89. Kratky, L.; Jirout, T. Biomass size reduction machines for enhancing biogas production. Chem. Eng. Technol. 2015, 34, 391-399. [CrossRef]

90. Matsakas, L.; Nitsos, C.; Vörös, D.; Rova, U.; Christakopoulos, P. High-titer methane from organosolv-pretreated spruce and birch. Energies 2017, 10, 263. [CrossRef]

91. Yi, H.; Han, Y.; Zhuo, Y. Effect of combined pretreatment of waste activated sludge for anaerobic digestion process. Procedia Environ. Sci. 2013, 18, 716-721. [CrossRef]

92. Navarro, R.R.; Otsuka, Y.; Matsuo, K.; Sasaki, K.; Sasaki, K.; Hori, T.; Habe, H.; Nakamura, M.; Nakashimada, Y.; Kimbara, K.; et al. Combined simultaneous enzymatic saccharification and comminution (SESC) and anaerobic digestion for sustainable biomethane generation from wood lignocellulose and the biochemical characterization of residual sludge solid. Bioresour. Technol. 2020, 300, 122622. [CrossRef]

93. Khan, M.U.; Ahring, B.K. Anaerobic digestion of biorefinery lignin: Effect of different wet explosion pretreatment conditions. Bioresour. Technol. 2020, 298, 122537. [CrossRef]

94. Dahunsi, S.O.; Adesulu-Dahunsi, A.T.; Osueke, C.O.; Lawal, A.I.; Olayanju, T.M.A.; Ojediran, J.O.; Izebere, J. Biogas generation from Sorghum bicolor stalk: Effect of pretreatment methods and economic feasibility. Energy Rep. 2019, 1, 584-593. [CrossRef]

95. Calise, F.; Cappiello, F.L.; Cimmino, L.; d'Accadia, M.D.; Vicidomini, M. A Review of the State of the Art of Biomethane Production: Recent Advancements and Integration of Renewable Energies. Energies 2021, 14, 4895. [CrossRef] 